\title{
GPR180 Gene
}

National Cancer Institute

\section{Source}

National Cancer Institute. GPR180 Gene. NCI Thesaurus. Code C153053.

This gene may be involved in signaling and vascular remodeling. 